NBER WORKING PAPER SERIES

\title{
WAS JACKSON POLLOCK THE GREATEST MODERN AMERICAN PAINTER? A QUANTITATIVE INVESTIGATION
}

\author{
David W. Galenson \\ Working Paper 8830 \\ http://www.nber.org/papers/w8830 \\ NATIONAL BUREAU OF ECONOMIC RESEARCH \\ 1050 Massachusetts Avenue \\ Cambridge, MA 02138 \\ March 2002
}

The views expressed herein are those of the author and not necessarily those of the National Bureau of Economic Research.

(C) 2002 by David W. Galenson. All rights reserved. Short sections of text, not to exceed two paragraphs, may be quoted without explicit permission provided that full credit, including (C) notice, is given to the source. 
Was Jackson Pollock the Greatest Modern American Painter?

A Quantitative Investigation

David W. Galenson

NBER Working Paper No. 8830

March 2002

\begin{abstract}
A survey of the illustrations in textbooks of modern art demonstrates that scholars do consider Jackson Pollock the most important modern American painter, but not by a wide margin over Jasper Johns and Andy Warhol, the leading artists of the following generation. The distribution of the illustrations furthermore reveals a sharp contrast in the careers of the major artists of these two generations: the Abstract Expressionists produced their most important contributions late in their careers, whereas their successors innovated early in theirs. This difference resulted from the differing approaches of the artists, for the Abstract Expressionists were experimental innovators, who developed new visual images by a process of trial and error, while the leading artists of the 1960s were conceptual innovators, whose work embodied new ideas.
\end{abstract}

\author{
David W. Galenson \\ Department of Economics \\ University of Chicago \\ 1126 E. 59th Street \\ Chicago, IL 60637 \\ and NBER \\ sogrodow@midway.uchicago.edu
}


In August of 1949, Life magazine published a feature article titled "Jackson Pollock: Is He the Greatest Living Painter in the United States?"1 The article was prompted by a growing recognition that Pollock was the leader of a group of artists centered in New York who were producing the most important new art of their time. The fame of Pollock, Willem de Kooning, Mark Rothko, and others in the group continued to grow, so that by 1955, when William Seitz completed the first major academic study of their art he concluded that it was nearly "impossible to fully convey the degree to which Abstract Expressionism has become a universal style." In 1955 , few in the art world could have predicted how quickly and how thoroughly Abstract Expressionism would be eclipsed by new styles devised by younger artists. The new styles did not belong to any single movement and differed greatly in appearance, but all were clearly recognized as challenges to Abstract Expressionism. Thus from 1958 through the 1960s, Jasper Johns, Robert Rauschenberg, Frank Stella, Andy Warhol, and a number of other young artists emerged as the leaders of the new generation.

Since the " 60 s, the influence of the new styles of that decade has grown. In view of this, it is now of some interest to ask whether art historians' assessments of the importance of the Abstract Expressionists' achievements have changed. In 1949, there was little doubt among experts that Jackson Pollock was the greatest living American painter. More than 50 years later, is he still considered the greatest artist from the extraordinary era when American painters dominated the world of advanced art, or has his reputation been surpassed by one or more of the leaders of the next generation?

To answer this question, this study will survey the opinions of art historians about the relative importance of the major American painters of this era. The evidence obtained from this 
survey will not only allow us to gauge Pollock's importance, but will also provide new insights into the contrasts between the art of the Abstract Expressionists and that of their successors. The Artists and the Evidence

The goal in choosing the artists to be studied here was to select the most important painters who lived and worked in the United States during the 1950s and '60s. This was done by using ten textbooks on the history of modern art published since $1993 .{ }^{3}$ The first step was to list all artists who had at least one painting reproduced in two or more of these ten books. The 29 artists on this list who were born in the US between 1900 and 1940 were placed in the sample, as were another six artists on the list who were born elsewhere in the same period but spent most of their careers in the US. The resulting sample of 35 painters is shown in Table 1.

Textbooks of art history are also the source of the evidence analyzed in this study. This evidence was drawn from all available books, published in English since 1980, that provide illustrated surveys of at least the entire period under consideration here. A total of 56 such books were found. ${ }^{4}$ The data set for this study was created by listing every reproduction of every work of art shown in these books by all of the 35 artists in the sample. ${ }^{5}$

Counting the illustrations contained in these 56 surveys of art history effectively allows us to draw on the judgments of scores of art scholars concerning which painters, and paintings, are judged most important. This approach is analogous to a citation study, in which the importance of a book or article is measured by the number of citations it receives in a specified set of books or journals. Yet using illustrations as the unit of analysis has the advantage that these are substantially more costly then written references. In addition to the printing costs, authors or publishers must usually pay for permission to reproduce each painting, and purchase 
or rent a suitable photograph. The resulting cost in time and money implies that authors would be more selective in their use of illustrations, and that illustrations may consequently provide a better indication than written references of what an author considers genuinely important. ${ }^{6}$ Rankings: Painters and Paintings

Table 2 presents the ranking of painters by total illustrations. Jackson Pollock leads the list with 135 illustrations, an average of more than two per book. He is clearly identified as the leading artist of his generation, with over $40 \%$ more illustrations than de Kooning and Rothko. Interestingly, however, the three artists immediately following Pollock are all of the following generation, and Pollock's total illustrations are less than 10\% greater than those of Jasper Johns. Neither generation dominates the top of the ranking; thus the top ten positions are divided evenly between the two cohorts.

Table 3 ranks individual paintings by total illustrations. De Kooning's Woman I is in first place, but its success is not overwhelming, as it appears in considerably less than half of the books, and leads Newman's Vir Heroicus Sublimis by just one illustration. Table 3 is headed by the same artists who dominate Table 2: all of the highest-ranked 11 paintings in Table 3, and 17 of the total of 21 works listed, were done by painters who were ranked in the top ten in Table 2 . Table 3 is also relatively evenly divided by generation, with nine paintings by artists born before 1920, and twelve by artists born after that date.

An interesting contrast appears in Table 4, which gives the ages of the artists when they executed the paintings listed in Table 3 . This shows a striking difference by generation in the artists' ages. The median age at which the Abstract Expressionists executed their nine entries in Table 3 was 40, compared to a median age of just 31 for the twelve entries of the next generation. 
None of the nine paintings by the first generation was done by an artist under the age of 38 , but ten of the twelve works by the second generation were done by artists younger than that, and fully half were made by artists aged 30 or younger.

Experimental and Conceptual Innovators

Table 4 raises an intriguing question: why did the Abstract Expressionists produce their most important paintings later in their lives than did the leading artists of the next generation? The answer to this question follows from the recognition that the careers of the Abstract Expressionists were systematically different from those of their successors. This difference is a consequence of the differing ways the two groups of artists arrived at their principal contributions.

The Abstract Expressionists were experimental innovators. They worked by a process of trial and error, motivated by aesthetic goals. They wished to create new visual representations of emotions and states of mind, but in advance they had no precise conception of either the process they should follow or what the results should look like. Their styles evolved as they worked, not only from one painting to the next, but even in the process of making a single painting. Thus Mark Rothko described his work as "a series of stumblings toward a clearer issue," and he spent long periods studying his paintings in progress, deciding how to continue: a biographer observed that "since the late 1940s Rothko, building up his canvases with thin glazes of quickly applied paint, had spent more time considering his evolving works than he had in the physical act of producing them." ${ }^{\prime 7}$ Like the other Abstract Expressionists, Rothko believed that progress only came slowly, in small increments. He made his trademark image of stacked rectangles the basis for hundreds of paintings over the course of two decades, explaining that "If a thing is worth 
doing once, it is worth doing over and over again - exploring it, probing it."

The absence of preconceived outcomes became a celebrated feature of Abstract Expressionism. Jackson Pollock's signature drip method of applying paint, with the inevitable spattering and puddling that could not be completely controlled by the artist, became the most familiar symbol of this lack of preconception, reinforced by Pollock's often-quoted statement, "When I am in my painting, I'm not aware of what I'm doing." For the Abstract Expressionists, creativity lay in the process of making their works, and preparation for individual paintings was consequently of little importance. Barnett Newman explained that he was a "direct" painter: "I have never worked from sketches, never planned a painting, never 'thought out' a painting before." ${ }^{10}$ In fact, since their goal was to draw on the unconscious to arrive at new images, the Abstract Expressionists purposely avoided plans that would constrain them. Pollock explained that 'I don't work from drawings, I don't make sketches and drawings and color sketches into a final painting. Painting, I think, today - the more immediate, the more direct - the greater the possibilities of making a direct - of making a statement."11 The form of the work would reveal itself in the process of making it: Pollock declared that "I have no fears about making changes, destroying the image, etc., because the painting has a life of its own. I try to let it come through." 12

Their lack of specific goals for their works meant that the Abstract Expressionists often found it difficult to decide when a painting was finished. Nor did they necessarily consider this an important issue. Newman in fact declared that "I think the idea of a 'finished' picture is a fiction."13 The absence of precise goals equally led the Abstract Expressionists to the recognition that they would not typically consider their paintings successful. Willem de Kooning told an 
interviewer that he considered his series of paintings of Women - which would come to be generally considered his greatest achievement - a failure, but that that hadn't fazed him, explaining:

I was never interested, you know, how to make a good painting. For many years I was not interested in making a good painting, you know, like you could say: now this is a really good painting or a perfect work. I didn't want to pin it down at all. I was interested in that before, but I found out it was not my nature. ${ }^{14}$

Unlike the Abstract Expressionists, the leading painters of the next generation did not belong to any single group or movement. Yet they did share a common concern with replacing the complexity of Abstract Expressionist gestures and symbols with simpler images and ideas, and in pursuing this goal they succeeded in replacing their predecessors' experimental method with a conceptual approach.

The art that came to dominate the 1960s was planned carefully in advance. Frank Stella explained that "the painting never changes once I've started to work on it. I work things out beforehand in the sketches."15 In this Roy Lichtenstein found common ground between his work's cartoon images and Stella's geometric patterns: "I think that is what's interesting people these days: that before you start painting the painting, you know exactly what it's going to look like." 16 The images in the work were intended to be straightforward: Jasper Johns explained to a critic that he had chosen to paint flags, targets, and numerals because they were "preformed, conventional, depersonalized, factual, exterior elements." 17

Because the significance of the work lay in its planning, the production of paintings was often described as perfunctory. Andy Warhol used mechanical devices, like silk screens, to make his paintings, because "hand painting would take much too long and anyway that's not the age 
we're living in. Mechanical means are today." ${ }^{\prime 18}$ Lichtenstein explained that "I want my painting to look as if it had been programmed. I want to hide the record of my hand." ${ }^{19}$ He stressed the contrast with his predecessors: "Abstract Expressionism was very human looking. My work is the opposite. It has a pseudomechanical look - as though it were done by a machine. ${ }^{20}$

The clarity associated with the preconception of their works meant that these younger artists knew when their paintings were finished. Frank Stella contrasted his cohort with the preceding one:

We believe that we can find the end, and that a painting can be finished. The Abstract Expressionists always felt the painting's being finished was very problematical. We'd more readily say that our paintings were finished and say, well, it's either a failure or it's not, instead of saying, well, maybe it's not really finished. ${ }^{21}$

The resolution of their works similarly came about quite differently. For Mark Rothko completion of a painting occurred "in a flash of recognition," because the picture had to be "a revelation, an unexpected and unprecedented resolution of an eternally familiar need;" for Jasper Johns, completing a painting involved a loss of interest: "I usually get bored before I finish.",22

The enormous differences in the practices of the artists of these two generations were directly associated with radically differing conceptions of their artistic goals. To the Abstract Expressionists art was a spiritual quest, and the artist was a seeker. In a letter published in the New York Times in 1943, Adolph Gottlieb and Mark Rothko explained their aesthetic beliefs, declaring that "To us art is an adventure into an unknown world, which can be explored only by those willing to take the risks.. ${ }^{23}$ Rejecting the view that subject matter was unimportant to the quality of art, they asserted that "the subject is crucial and only that subject-matter is valid which is tragic and timeless. ${ }^{24}$ Barnett Newman declared that in their work the Abstract Expressionists 
created "a truly abstract world which can be discussed only in metaphysical terms." 25 Asked about the meaning of his art for society, Newman replied that his work was an assertion of freedom, and if it were understood "it would mean the end of all state capitalism and totalitarianism." 26 The leading artists of the next generation made much more limited claims for their work. To them art consisted of a series of technical problems, to which they believed they could find solutions. Jasper Johns told an interviewer that "I'm neither a teacher nor an author of manifestos. I don't think along the same lines as the Abstract Expressionists who took those sorts of things all too seriously." 27 In 1965 Frank Stella made a similar comparison of artistic goals, and explained that he and his contemporaries were interested in more concrete problems:

[A]s for the transcendental or metaphysical things, I simply don't understand them, and I'm honestly not interested in them. It seems to be something that was almost a generation thing. I can't think of any artist in my generation or any artists that I really know that are working right now that could be interested in that either or even understand it. It seems it's something that's sort of gone by or passed by on the level of ideas. Maybe it's not such a good thing, but the ideas now are much more simply technical or simply pedestrian, simply involved in the making of the actual object. That's about all I can think about. ${ }^{28}$

A generation dominated by experimental innovators was thus followed by one dominated by conceptual innovators. The process began in the late 1950s, when Jasper Johns and Robert Rauschenberg first attracted attention in New York's art world, and continued with the emergence of Pop Art early in the 1960s and of Minimalism later in the decade. The replacement of a generation of artists whose work was based on seeking by a younger generation whose work was based on finding did not altogether escape the notice of art world observers. So for example the critic David Sylvester wrote of this shift in 1969: 
Some artists like to think they are working in the dark, others that they are firmly in control. The preference seems almost more a matter of generation than of individual temperament. Most of the artists whose styles were formed in the 1940s subscribed to the idea that making art meant feeling one's way through unknown territory... Art was the lonely journey of existentialist man...and this ideal of the journey was shared by a multitude of artists... This common ethical ideal led to a generally shared attribute of style: the way in which the work was made was more or less visible in the end-product.

The typical art of the Sixties is as different from this as Colonel Borman's journey to the moon is from Lévi-Strauss's journey into the tropics. It is carefully planned, tightly organized, precise in execution. It is technological (as in its use of silk-screen and spray-gun or as in sculpture ordered from the factory by telephone)... It is sure of itself and has an air of certainty and decision. The artist, like a good executive, makes up his mind what he will do and does it, or gets it done to his specifications. ${ }^{29}$

Yet what was not generally recognized, or understood, is that this generational shift in approach had profound consequences for the timing of artists' life cycles. Recent research has begun to demonstrate that the careers of experimental and conceptual artists differ considerably. The long periods of trial and error typically required for important experimental innovations mean that they rarely occur early in an artist's career. In contrast conceptual innovations, which can be made much more quickly as new ideas are formulated, can occur at any age. Radical conceptual innovations are in fact most often made early in artists' careers, by painters who are not yet accustomed to existing conventions and methods and are consequently more likely to be able to perceive and appreciate more extreme deviations from these accepted practices. ${ }^{30}$

\section{Old Masters and Young Geniuses}

The differences in the life cycles of the Abstract Expressionists and their successors can be explored using the data set constructed for this study. The data are most abundant for the 
leading artists, and this investigation will therefore concentrate on the ten artists who hold the top places in Table 2; these are the artists who had an average of more than one illustration per book. As noted above, five of these artists were Abstract Expressionists, and five were from the next generation.

Table 5 presents a measure of the timing of the major contribution of each of these artists, by listing the year from which each had the most illustrations. By this measure the Abstract Expressionists' peak years occurred at a median age of 46, whereas the median age for the artists of the next generation was just 34. Four of the five Abstract Expressionists had their peak years after the age of 40, while four of the five leaders of the next generation had their peak years before that age. The Abstract Expressionists thus clearly produced their most important work at considerably older ages than did their successors.

Table 5 also shows that the conceptual artists of the second generation not only made their major contributions at younger ages than did their predecessors, but that they made them within shorter periods of time. Thus although Pollock ranked first in Table 3 with the greatest number of total illustrations, he stands only in a tie for third place in Table 5. Both Warhol and Johns had more important individual years than Pollock, and even Lichtenstein, who had nearly a third less total illustrations than Pollock, had a single year that matched Pollock's best. Conceptual innovations embody new ideas, and are generally arrived at and presented more quickly than the visual advances of experimental innovators. Johns, Warhol, and Lichtenstein could therefore make and present their innovations in a much shorter period than Pollock and his colleagues had.

Warhol's position at the top of Table 5 is a consequence of the fact that his early Pop 
works constituted one of the most influential contributions in American modern art. Critic John Coplans explained that these works embodied two important formal innovations: "First, the actual as against the simulated use of an anonymous and mechanical technique, and second, the use of serial forms." ${ }^{\text {31 }}$ Warhol introduced both of these innovations in 1962. Early in that year Warhol began to use stencils, and with them he made the 32 paintings of Campbell's soup cans that were exhibited at his first one-person show at Los Angeles' Ferus Gallery in June. ${ }^{32}$ In July Warhol discovered that he could work much more quickly by silkscreening his paintings. His two paintings listed in Table 3 - the Tate Gallery's Monroe Diptych and the Whitney Museum's Green Coca-Cola Bottles - were made with this technique. All of his work of 1962 made use of serial forms, usually in the repeated appearance of images in series of separate works, such as the soup cans and the portraits of Marilyn Monroe, and often also in the repetition of an image within a given work; so for example the Monroe Diptych presents Monroe's portrait 50 times, and Green Coca-Cola Bottles contains more than 100 images of bottles. Both of Warhol's innovations were the product of new conceptions, and could be introduced immediately, without the need for experimentation. Thus for example having just begun to use silk screens in July, Warhol could use them to produce more than 100 paintings in the next three months, in time to make his new screened paintings the basis for his first New York one-person show, at the Stable Gallery, in November. ${ }^{33}$ The Stable show was a great success, as almost all the works sold, including a portrait of Monroe that curator William Seitz bought for the Museum of Modern Art. ${ }^{34}$ The extreme concentration of Warhol's major contribution in a short period is emphasized not only by Table 5, which shows that the single year of 1962 accounts for $45 \%$ of his total illustrations - the highest share for any of the leading artists - but also by the fact that among all 
his works only the Monroe Diptych and Green Coca-Cola Bottles appear in as many as five textbooks. $^{35}$

For experimental artists, experience as an artist allows the accumulation of knowledge that leads to innovations, whereas for conceptual artists a lack of experience in fine art may be key in allowing the departure into radically new practices. Table 6 gives an indication of the timing of each artist's major contribution within the context of his career. For each artist, in addition to the artist's age in his peak year, the table shows how old each artist was in the earliest and latest years from which any of his work appeared in the textbooks.

Table 6 clearly reveals the slower maturation of the Abstract Expressionists than of their successors. Among the former, only Newman had an interval of less than 15 years between the date of his first illustrated work and his best year. In contrast, none of the five painters of the second generation had a gap of more than 10 years between their first illustrated work and their peak year. Indeed the most remarkable feature of Table 6 is that for both Johns and Stella their peak years were the earliest ones from which they had any work illustrated, and for both Lichtenstein and Warhol the gap from their earliest illustrated work to their best was just two years. This underscores the fact that for these four conceptual innovators, their major contributions were their first significant efforts. For Johns and Stella, this was work done in their early 20s, but for Lichtenstein and Warhol it was done at older ages, for both made their breakthroughs as artists only after spending extended periods earning a living at jobs that did not allow them to concentrate primarily on their own painting. ${ }^{36}$

Table 7 provides further evidence on the timing of these artists' careers, by showing the proportions of each artist's total illustrations that represent work done before and after the single 
year judged most important by the art historians. The Abstract Expressionists all produced substantial bodies of significant work prior to their peaks: for all five, at least $20 \%$ of their total illustrations show work done before their peak years, and for both Pollock and Rothko this proportion is fully half. In contrast, of the five younger artists, only for Rauschenberg does work done before his peak year account for more than $20 \%$ of his total illustrations, while for Johns, Stella, and Warhol these proportions are below 5\%. For three of the Abstract Expressionists, the share of illustrations accounted for by paintings done prior to their peaks is actually greater than the share of work done after those peaks, whereas this is not true for any of the later artists.

An example of the gradual process by which the Abstract Expressionists developed their art is afforded by Pollock's career. Table 8 presents a full listing of the illustrations of his work by year of execution. This identifies Pollock's first important year as 1943, the time of his first one-person show at Peggy Guggenheim's gallery, Art of this Century. Pollock had been working under the influence of Surrealism for several years, but it was in 1943 that he first began to use this influence in an original way, in paintings like Pasiphae (illustrated in five books) and Guardians of the Secret (6 illustrations). Late in the year Pollock painted Mural (5 illustrations) as a commission for Guggenheim. This began to anticipate Pollock's major work: the painting was the largest he had made to date, and in it he began to use line for its own sake, rather than for creating figures or defining planes, as in all earlier painting. The next important years identified by Table 8 are 1947-48. These began what is considered Pollock's classic period, as in 1947 he produced the first paintings in his signature method of applying paint, by dripping it onto canvases laid flat on the floor. Landmark paintings from these years include Cathedral (5 illustrations) and Number 1, 1948 (7 illustrations). In 1950, Pollock's peak year in Table 8, he 
produced the work, including his two entries in Table 3, Lavender Mist (12 illustrations) and Autumn Rhythm (13 illustrations), that is considered his finest. Working with large formats, he used the drip method to create all-over compositions that broke with tradition by having no specific points of emphasis. Pollock described this innovation by saying "My paintings do not have a center," and its influence changed the course of modern painting. ${ }^{37}$ Thus in 1967 the Minimalist sculptor Donald Judd would write that "I think it's clear that Pollock created the large scale, wholeness, and simplicity that have become common to almost all good work." ${ }^{38}$ Table 8 documents the timing of the incremental process by which Pollock developed each of the elements of his technique into these revolutionary results.

The evidence of Tables 7 and 8 thus reinforces the recognition that much of the interest in the Abstract Expressionists' careers lies in the experimental process by which they arrived at their greatest work. In contrast, Table 7 shows that for the later artists the discontinuities in their careers represented by their major contributions mean that their prior work is of little or no interest, and that for scholars these artists' careers effectively begin with their early conceptual breakthroughs. A remarkable consequence of the early achievements of the younger conceptual artists is shown in Table 9. Both Jasper Johns and Frank Stella had their first New York oneman gallery shows after they had done the work that would later be judged their most important, while Andy Warhol had his first show in the same year in which he produced what scholars would consider his best work. In contrast, all the Abstract Expressionists had their first gallery shows before - and usually well before - producing their most important work. The conceptual revolution of the " 60 s thus produced a new phenomenon in the history of modern art, in which the work that first introduced an artist to the art world would often be that which would remain 
his most important.

\section{$\underline{\text { Careers and Conflicts }}$}

The differences in career patterns documented above help us not only to understand the differences in the creative processes of these two types of artist, but also to gain perspective on the violence of the conflict that occurred in the art world when the two generations considered here clashed in the late 1950s and early '60s. A dramatic and celebrated instance was occasioned by an exhibition in 1962 .

Sidney Janis was a wealthy clothing manufacturer and art collector who opened an art gallery in New York in 1948. His gallery quickly gained prominence, for he not only exhibited the work of most of the emerging leaders of Abstract Expressionism, but also that of such important European artists as Bonnard, Klee, Miró, and Mondrian. As the critic Clement Greenberg explained in a 1958 tribute to the dealer, Janis' exhibition practices had helped to establish the legitimacy of the Americans, for his policy "not only implied, it declared, that Pollock, de Kooning, Kline, Guston, Rothko, and Motherwell were to be judged by the same standards as Matisse and Picasso, without condescension, without making allowances." Greenberg observed that in the late " 40 s "the real issue was whether ambitious artists could live in this country by what they did ambitiously. Sidney Janis helped as much as anyone to see that it was decided affirmatively. ${ }^{" 39}$

In the fall of 1962, Janis welcomed a new generation of artists in a group show he titled

"The New Realism." The exhibition included paintings by Roy Lichtenstein, Andy Warhol, and a number of other Pop artists. In the catalogue Janis hailed the arrival of a new movement:

Reaction and change in the continuity of art have never 
before undergone the rapid nor unpredictable succession of metamorphoses as they have in the twentieth century.

Cubism, Surrealism, Dadaism and later Abstract Expressionism, to name only a few, were each in turn ardent dissents from existing creative art forms and frequently before these forms were even accepted. The originality of each succeeding movement, challenged or maligned as it was, ultimately found its recognition.

Today's Factual artist, and the work of these artists make up the present exhibition, belong to a new generation (age average about 30) whose reaction to Abstract Expressionism is still another manifestation in the evolution of art. As the Abstract Expressionist became the world recognized painter of the 50s, the new Factual artist (referred to as the Pop Artist in England ... and here as in France, as the New Realist) may have already proved to be the pacemaker of the $60 \mathrm{~s} .{ }^{40}$

The show had a powerful impact, both on the large crowds of curious spectators it attracted, and on Janis' established artists, as Adolph Gottlieb, Philip Guston, Robert Motherwell, and Mark Rothko resigned from the gallery in protest. Janis claimed to be both startled and disappointed at the older artists' action, which he considered hypocritical: "It took me completely by surprise. Here we had been showing Pollock cheek-by-jowl with Léger, and de Kooning with Mondrian, and Kline with Klee, but when we took up the next generation our artists were furious." ${ }^{\prime 1}$ Yet critic Calvin Tomkins explained that the Abstract Expressionists could not see the parallel between the two episodes:

The Abstract Expressionists' anger was not really so hard to understand. They had struggled for many years in total obscurity, their achievements recognized only by one another... The recognition that they had so recently and so arduously won was now being usurped, or so they believed, by a new generation of brash youngsters who have become "artists overnight," who had not earned anything the hard way, and whose most apparent common bond seemed to be mockery and rejection of all serious art, especially Abstract Expressionism. Pollock and de Kooning and Rothko and Newman had not repudiated Picasso, Mondrian, 
and Léger. They had worshiped the European masters, while striving heroically to go beyond them. Now, suddenly, heroism and high art were out of style. ${ }^{42}$

As Tomkins recognized, the Abstract Expressionists' anger at Pop art was not simply a product of jealousy at the younger artists' quick commercial success. Its deeper cause lay in the inability of a generation of experimental artists to appreciate the achievement of a younger generation of conceptual innovators. For Rothko and his friends, real artistic achievement was only possible through long and difficult struggles. Consequently, for them the conceptual art of the ' $60 \mathrm{~s}$ was not only not good art, but it was not art at all. Thus for example when Motherwell first saw Frank Stella's early paintings, he remarked 'It's very interesting, but it's not painting." "43 Similarly, the critic Harold Rosenberg, a friend and early supporter of the Abstract Expressionists, described Andy Warhol as "a new kind of artist: 'Media celebrity and manufacturer of art substitutes."

The Janis episode underscores the fact that the differences in the careers of experimental and conceptual artists that appear in the quantitative measures of this paper were associated with fundamental differences in the artists' goals and in their very conception of the purposes of art. To the Abstract Expressionists, whose careers - and lives - were dedicated to a visual art, the conceptual art of their successors could never be more than a cynical and opportunistic strategy. $\underline{\text { Conclusion }}$

If the illustrations in textbooks were considered as ballots in a competition like the movies' Academy Awards, Table 2 shows that Jackson Pollock would win the award for the greatest overall achievement by a modern American painter. This would not come as a great surprise to many leading artists of this era. Thus for example in one recent interview the sculptor 
Richard Serra observed that "We evaluate artists by how much they are able to rid themselves of convention, to change history. Well, I don't know anyone since Pollock who has altered the form or the language of painting as much as he did," and in another the painter Cy Twombly remarked that "To me, Pollock is the height of American painting." ${ }^{\text {" } 55}$ Yet Pollock would not sweep these hypothetical Oscars, for Table 5 shows that Andy Warhol's seminal Pop paintings from 1962 would win him an award for the greatest achievement in a single year, and Table 3 shows that de Kooning's Woman I would have the honor of being considered the greatest American modern painting. Jasper Johns might receive an award for the most impressive debut, as the paintings of flags and targets that made 1955 his peak year were not only the earliest of his paintings that received votes, but were ranked in Table 5 as the second most important contribution made by a modern American painter in a single year. And de Kooning might also receive a special award for endurance, in recognition of the evidence of Table 6 that he produced work deemed worthy of scholarly attention over a period of more than 60 years.

If a similar process were used to make awards to the great painters who worked in France and dominated modern art during its first century, virtually all significant honors would be captured by a single towering figure. ${ }^{46}$ The absence of such a dominant figure in the present study, and the even balance of these awards by generation, appear to reflect a broad consensus of art historians. Thus Jackson Pollock does appear in retrospect as the greatest of modern American painters, but not by an overwhelming margin. Similarly whereas it is widely agreed that the leading American artists of the next generation succeeded the Abstract Expressionists as the major producers of innovations in modern art, there is also a consensus that they did not overshadow their predecessors. 
The Abstract Expressionists revolutionized modern painting during the late 1940s and early '50s, and their successors again revolutionized it in the late ' 50 s and the early ' 60 s. Yet this study has highlighted the dramatic difference in the ways these revolutions were made. The Abstract Expressionists produced their innovations gradually, through time-consuming and painstaking experimentation aimed at capturing complex and elusive visual effects. In contrast, the artists of the next generation produced their innovations abruptly, by making new kinds of art from more straightforward images that came directly from new ideas. The Abstract Expressionists' art of perception gave way to new movements based on conception. And the creative lives of the artists contrasted just as sharply. The Abstract Expressionists made their greatest contributions only after decades of searching, whereas their successors produced their major works by making dramatic discoveries early in their careers. 


\section{$\underline{\text { Footnotes }}$}

I thank Peter Northup for research assistance, and the National Science Foundation for financial support.

1. Reprinted in Pepe Karmel, ed., Jackson Pollock (New York: Museum of Modern Art, 1999), pp. 63-64.

2. Seitz, "Abstract-Expressionist Painting in America," (Ph.D. dissertation, Princeton University, 1995), p. 442.

3. See the appendix for a list these books.

4. These are listed in the appendix.

5. As described above, the selection of the artists was done based on reproductions of paintings in the 10 books selected. The 35 artists in Table 1 are consequently primarily painters. In constructing the data set, however, reproductions of works of art in all media were included.

6. For additional discussion of the use of textbook illustrations, see David W. Galenson, Painting outside the Lines (Cambridge: Harvard University Press, 2001), pp. 25-26.

7. James E. B. Breslin, Mark Rothko (Chicago: University of Chicago Press, 1993), pp. 232469.

8. Breslin, Mark Rothko, p. 526.

9. B. H. Friedman, Jackson Pollock (New York: Da Capo Press, 1995), p. 100.

10. Barnett Newman, Selected Writings and Interviews (Berkeley: University of California Press, 1992), p. 248.

11. Karmel, Jackson Pollock, p. 22.

12. Karmel, Jackson Pollock, p. 18.

13. Newman, Selected Writings and Interviews, p. 240.

14. David Sylvester, Interviews with American Artists (New Haven: Yale University Press, 2001), p. 52.

15. Caroline A. Jones, Machine in the Studio (Chicago: University of Chicago Press, 1996), p. 90.

16. David Sylvester, About Modern Art (New York: Henry Holt, 1997), p. 230. 
17. Jasper Johns, Writings, Sketchbook Notes, Interviews (New York: Museum of Modern Art, 1996), p. 113.

18. Jones, Machine in the Studio, pp. 197-98.

19. Steven Henry Madoff, ed., Pop Art (Berkeley: University of California Press, 1997), p. 198.

20. John Gruen, The Artist Observed (Chicago: a cappella books, 1991), p. 225.

21. Gregory Battcock, ed., Minimal Art (Berkeley: University of California Press, 1995), p. 161.

22. Breslin, Mark Rothko, pp. 239-40; Johns, Writings, Sketchbook Notes, Interviews, p. 114.

23. Breslin, Mark Rothko, p. 193.

24. Breslin, Mark Rothko, p. 194.

25. Newman, Selected Writings and Interviews, p. 163.

26. Newman, Selected Writings and Interviews, p. 251.

27. Johns, Writings, Sketchbook Notes, Interviews, p. 136.

28. Sylvester, Interviews with American Artists, p. 197.

29. Sylvester, About Modern Art, pp. 229-30.

30. For additional discussion see Galenson, Painting outside the Lines, Chapter 5.

31. Madoff, Pop Art, p. 296.

32. Rainer Crone, "Form and Ideology," in Gary Garrels, ed., The Work of Andy Warhol (New York: Dia Art Foundation, 1989), p. 86.

33. Victor Bockris, Warhol (New York: Da Capo Press, 1997), pp. 151-56.

34. Bockris, Warhol, p. 156.

35. Interestingly, in spite of the enormous importance of Warhol's contribution of 1962, no individual work of his stands higher than seventh in Table 3. This contrasts sharply with the pattern for earlier conceptual innovators, whose greatest contributions were typically embodied in a single major breakthrough work; e.g. see Galenson, "Quantifying Artistic Success: Ranking French Painters - and Paintings - from Impressionism to Cubism," Historical Methods, forthcoming. The obvious source of the failure of this pattern to 
apply to Warhol is the nature of his innovations, for both tended to deemphasize the significance of individual paintings in favor of a body of work as a whole. For discussion see Galenson, "Masterpieces and Markets: Why the Most Famous Modern Paintings Are Not By American Artists," Historical Methods, forthcoming.

36. Warhol worked as a commercial artist into the early 1960s; Bockris, Warhol, pp. 131, 145. Lichtenstein worked as a draftsman in Cleveland until 1957, and produced his innovative paintings only after taking a job teaching art at Rutgers in 1960; Gruen, The Artist Observed, p. 222.

37. Karmel, Jackson Pollock, p. 78.

38. Karmel, Jackson Pollock, p. 116.

39. Clement Greenberg, The Collected Essays and Criticism, Volume 4 (Chicago: University of Chicago Press, 1993), p. 53.

40. Sidney Janis, "On the Theme of the Exhibition," in Madoff, Pop Art, p. 39.

41. Calvin Tomkins, Off the Wall: Robert Rauschenberg and the Art World of Our Time (New York: Penguin Books, 1981), p. 185.

42. Ibid., p. 185.

43. Thierry de Duve, Kant after Duchamp (Cambridge: MIT Press, 1996), p. 216.

44. Harold Rosenberg, The Case of the Baffled Radical (Chicago: University of Chicago Press, 1985), p. 263.

45. Michael Kimmelman, Portraits (New York: Random House, 1998), p. 54; Sylvester, Interviews with American Artists, p. 179.

46. Galenson, "Quantifying Artistic Success." 
Table 1: Artists Included in this Study

\begin{tabular}{|c|c|c|c|}
\hline Artist & Country of birth & Year of birth & Year of death \\
\hline Diebenkorn, Richard & U.S. & 1922 & 1993 \\
\hline Estes, Richard & U.S. & 1936 & \\
\hline Flack, Audrey & U.S. & 1931 & \\
\hline Francis, Sam & U.S. & 1923 & 1994 \\
\hline Frankenthaler, Helen & U.S. & 1928 & \\
\hline Golub, Leon & U.S. & 1922 & \\
\hline Gorky, Arshile & Armenia & 1904 & 1948 \\
\hline Gottlieb, Adolph & U.S. & 1903 & 1974 \\
\hline Guston, Philip & Canada & 1913 & 1980 \\
\hline Hockney, David & Great Britain & 1937 & \\
\hline Johns, Jasper & U.S. & 1930 & \\
\hline Kline, Franz & U.S. & 1910 & 1962 \\
\hline de Kooning, Willem & Holland & 1904 & 1997 \\
\hline Krasner, Lee & U.S. & 1908 & 1984 \\
\hline Lawrence, Jacob & U.S. & 1917 & 2000 \\
\hline LeWitt, Sol & U.S. & 1928 & \\
\hline Lichtenstein, Roy & U.S. & 1923 & 1997 \\
\hline Louis, Morris & U.S. & 1912 & 1962 \\
\hline Marden, Brice & U.S. & 1938 & \\
\hline Martin, Agnes & Canada & 1912 & \\
\hline Motherwell, Robert & U.S. & 1915 & 1991 \\
\hline Neel, Alice & U.S. & 1900 & 1984 \\
\hline Newman, Barnett & U.S. & 1905 & 1970 \\
\hline Noland, Kenneth & U.S. & 1924 & \\
\hline Pearlstein, Philip & U.S. & 1924 & \\
\hline
\end{tabular}




\begin{tabular}{|l|c|c|c|}
\hline Pollock, Jackson & U.S. & 1912 & 1956 \\
\hline Rauschenberg, Robert & U.S. & 1925 & \\
\hline Reinhardt, Ad & U.S. & 1913 & 1967 \\
\hline Rivers, Larry & U.S. & 1923 & \\
\hline Rosenquist, James & U.S. & 1933 & \\
\hline Rothko, Mark & Russia & 1903 & 1970 \\
\hline Stella, Frank & U.S. & 1936 & \\
\hline Still, Clyfford & U.S. & 1904 & 1980 \\
\hline Twombly, Cy & U.S. & 1928 & \\
\hline Warhol, Andy & U.S. & 1928 & 1987 \\
\hline
\end{tabular}

Source: see text 
Table 2: Ranking of Artists by Total Illustrations

\begin{tabular}{|c|c|c|c|}
\hline Artist & Total Illustrations & Artist & Total Illustrations \\
\hline 1 Pollock & 135 & 19 LeWitt & 30 \\
\hline 2 Johns & 124 & 20 Estes & 28 \\
\hline 3 Warhol & 114 & 20 Noland & 28 \\
\hline 4 Rauschenberg & 106 & 22 Reinhardt & 26 \\
\hline 5 de Kooning & 94 & 23 Diebenkorn & 23 \\
\hline 6 Lichtenstein & 93 & 24 Gottlieb & 21 \\
\hline 7 Rothko & 91 & 25 Rivers & 19 \\
\hline 8 Stella & 71 & 26 Golub & 17 \\
\hline 9 Gorky & 66 & 27 Francis & 14 \\
\hline 10 Newman & 63 & 27 Martin & 14 \\
\hline 11 Hockney & 48 & 27 Pearlstein & 14 \\
\hline 12 Guston & 45 & 30 Twombly & 13 \\
\hline 13 Louis & 43 & 31 Flack & 10 \\
\hline 13 Motherwell & 43 & 31 Krasner & 10 \\
\hline 15 Frankenthaler & 37 & 31 Marden & 10 \\
\hline 15 Kline & 37 & 34 Lawrence & 8 \\
\hline 17 Rosenquist & 32 & 35 Neel & 7 \\
\hline 17 Still & 32 & & \\
\hline
\end{tabular}

Source: This and subsequent tables are based on the data set constructed for this study. See text and appendix for description. 
Table 3: Ranking of Paintings by Total Illustrations

\begin{tabular}{|c|c|c|c|c|}
\hline Rank & Illustrations & Artist, Title & Date & Location \\
\hline 1 & 20 & de Kooning, Woman I & 1952 & New York \\
\hline 2 & 19 & Newman, Vir Heroicus Sublimis & 1951 & New York \\
\hline 3 & 17 & Lichtenstein, Whaam! & 1963 & London \\
\hline 4 & 15 & de Kooning, Excavation & 1950 & Chicago \\
\hline 4 & 15 & Rauschenberg, Bed & 1955 & New York \\
\hline 4 & 15 & Rauschenberg, Monogram & 1959 & Stockholm \\
\hline 7 & 13 & Gorky, The Liver is the Cock's Comb & 1944 & Buffalo \\
\hline 7 & 13 & Johns, Flag & 1955 & New York \\
\hline 7 & 13 & Johns, Three Flags & 1958 & New York \\
\hline 7 & 13 & Pollock, Autumn Rhythm & 1950 & New York \\
\hline 7 & 13 & Warhol, Marilyn Diptych & 1962 & London \\
\hline 12 & 12 & Frankenthaler, Mountains and Sea & 1952 & Washington, D.C. \\
\hline 12 & 12 & Johns, Target with Four Faces & 1955 & New York \\
\hline 12 & 12 & Pollock, Lavender Mist: Number 1, 1950 & 1950 & Washington, D.C. \\
\hline 15 & 11 & Rosenquist, $F-111$ & 1965 & Private collection \\
\hline 16 & 10 & Hockney, A Bigger Splash & 1967 & London \\
\hline 16 & 10 & de Kooning, Woman and Bicycle & 1953 & New York \\
\hline 16 & 10 & Warhol, Green Coca-Cola Bottles & 1962 & New York \\
\hline 19 & 9 & Gorky, Garden in Sochi & 1944 & New York \\
\hline 19 & 9 & Lichtenstein, Drowning Girl & 1963 & New York \\
\hline 19 & 9 & $\begin{array}{l}\text { Motherwell, Elegy to the Spanish } \\
\text { Republic, No. } 34\end{array}$ & 1954 & Buffalo \\
\hline
\end{tabular}


Table 4: Ages at Which Artists Executed Paintings Listed in Table 3, by Generation

\begin{tabular}{|c|c|c|c|}
\hline Artist Born $1900-20$ & Age & Artists Born $1921-40$ & Age \\
\hline de Kooning, Woman I & 48 & Lichtenstein, Whaam! & 40 \\
\hline Newman, Vir Heroicus Sublimis & 46 & Rauschenberg, Bed & 30 \\
\hline de Kooning, Excavation & 46 & Rauschenberg, Monogram & 34 \\
\hline Gorky, The Liver is the Cock's Comb & 40 & Johns, Flag & 25 \\
\hline Pollock, Autumn Rhythm & 38 & Johns, Three Flags & 28 \\
\hline Pollock, Lavender Mist & 38 & Warhol, Marilyn Diptych & 34 \\
\hline de Kooning, Woman and Bicycle & 49 & Frankenthaler, Mountains and Sea & 24 \\
\hline Gorky, Garden in Sochi & 40 & Johns, Target with Four Faces & 25 \\
\hline \multirow{4}{*}{$\begin{array}{l}\text { Motherwell, Elegy to the Spanish } \\
\text { Republic, No. } 34\end{array}$} & 39 & Rosenquist, $F-111$ & 32 \\
\hline & & Hockney, A Bigger Splash & 30 \\
\hline & & Warhol, Green Coca-Cola Bottles & 34 \\
\hline & & Lichtenstein, Drowning Girl & 40 \\
\hline
\end{tabular}


Table 5: Artist's Age in Year of Most Illustrations, for Leading Artists

\begin{tabular}{|l|l|c|c|c|c|}
\hline Rank & Artist & Year & Illustrations & $\begin{array}{c}\text { Percent of artist's } \\
\text { total illustrations }\end{array}$ & Age \\
\hline \hline 1 & Warhol & 1962 & 51 & 45 & 34 \\
\hline 2 & Johns & 1955 & 43 & 35 & 25 \\
\hline 3 & Lichtenstein & 1963 & 39 & 42 & 40 \\
\hline 3 & Pollock & 1950 & 39 & 29 & 38 \\
\hline 5 & Gorky & 1944 & 29 & 44 & 40 \\
\hline 6 & Rauschenberg & 1959 & 24 & 23 & 34 \\
\hline 7 & de Kooning & 1952 & 23 & 24 & 48 \\
\hline 8 & Newman & 1951 & 19 & 30 & 46 \\
\hline 9 & Stella & 1959 & 12 & 17 & 23 \\
\hline 10 & Rothko & 1957 & 11 & 12 & 54 \\
\hline
\end{tabular}


Table 6: Ages of Leading Artists in the Years of their Earliest, Most, and Latest Illustrations

\begin{tabular}{|l|c|c|c|}
\hline Artist & Earliest & Most & Latest \\
\hline \hline Born $1900-20$ & 23 & 40 & 43 \\
\hline Gorky & 17 & 48 & 80 \\
\hline de Kooning & 40 & 46 & 65 \\
\hline Newman & 23 & 38 & 43 \\
\hline Pollock & 35 & 54 & 67 \\
\hline Rothko & & & \\
\hline & & & 62 \\
\hline Born 1921 - 40 & 25 & 25 & 63 \\
\hline Johns & 38 & 40 & 51 \\
\hline Lichtenstein & 24 & 34 & 54 \\
\hline Rauschenberg & 23 & 23 & 58 \\
\hline Stella & 32 & 34 & \\
\hline Warhol & & & \\
\hline
\end{tabular}


Table 7: Distributions of Illustrations Over Artists' Careers

\begin{tabular}{|l|c|c|c|}
\hline \multirow{2}{*}{ Artist } & \multicolumn{3}{l}{ Percentage of artist's total illustrations that represent work done: } \\
& Prior to peak year & In peak year & \\
\hline \hline Born $1900-20$ & 21 & 44 & 35 \\
\hline Gorky & 33 & 24 & 43 \\
\hline de Kooning & 38 & 30 & 32 \\
\hline Newman & 50 & 29 & 21 \\
\hline Pollock & 54 & 12 & 34 \\
\hline Rothko & & & \\
\hline & & & 65 \\
\hline Born 1921 - 40 & 0 & 35 & 41 \\
\hline Johns & 17 & 42 & 42 \\
\hline Lichtenstein & 35 & 23 & 83 \\
\hline Rauschenberg & 0 & 17 & 52 \\
\hline Stella & 3 & 45 & \\
\hline Warhol & & & \\
\hline
\end{tabular}


Table 8: Illustrations of Paintings by Jackson Pollock, by Year of Execution

\begin{tabular}{|c|c||c|c|}
\hline Year & Total Illustrations & Year & Total Illustrations \\
\hline \hline 1935 & 1 & 1947 & 12 \\
\hline 1937 & 1 & 1948 & 13 \\
\hline 1938 & 2 & 1949 & 3 \\
\hline 1940 & 4 & 1950 & 39 \\
\hline 1941 & 2 & 1951 & 6 \\
\hline 1942 & 3 & 1952 & 8 \\
\hline 1943 & 19 & 1953 & 11 \\
\hline 1944 & 2 & 1954 & 1 \\
\hline 1946 & 6 & 1955 & 2 \\
\hline
\end{tabular}


Table 9: Ages of Leading Artists at the Time of Their First One-Man New York Gallery Exhibitions

\begin{tabular}{|c|c|c|}
\hline & Age at First Show & Peak Year \\
\hline \multicolumn{3}{|l|}{ Born $1900-20$} \\
\hline Gorky & 34 & 40 \\
\hline de Kooning & 44 & 48 \\
\hline Newman & 45 & 46 \\
\hline Pollock & 31 & 38 \\
\hline Rothko & 30 & 54 \\
\hline \multicolumn{3}{|l|}{ Born $1921-40$} \\
\hline Johns & 28 & 25 \\
\hline Lichtenstein & 28 & 40 \\
\hline Rauschenberg & 26 & 34 \\
\hline Stella & 24 & 23 \\
\hline Warhol & 34 & 34 \\
\hline
\end{tabular}

Source: Age at First Show: Galenson, Painting outside the Lines, Appendix C, pp. 191-92. Peak Year: Table 5. 
Appendix: The 56 books surveyed for this study are listed here, ordered by date of publication. The ten books also used to select the artists for the study are indicated by asterisks.

1. Lynton, Norbert, The Story of Modern Art (Ithaca: Cornell University Press, 1980).

2. Osborne, Harold, editor, The Oxford Companion to Twentieth-Century Art (Oxford: Oxford University Press, 1981).

3. Russell, John, The Meanings of Modern Art (New York: Museum of Modern Art, 1981).

4. Ashton, Dore, American Art Since 1945 (New York: Oxford University Press, 1982).

5. Hughes, Robert, The Shock of the New (New York: Alfred A. Knopf, 1982).

6. Collins, Judith; John Welchman, David Chandler, and David A. Anfam, Techniques of Modern Art (London: Macdonald, 1983).

7. Cornell, Sara, Art: A History of Changing Style (Oxford: Phaidon Press, 1983).

8. Britsch, Ralph A., and Todd A. Britsch, The Arts in Western Culture (Englewood Cliffs, NJ: Prentice-Hall, 1984).

9. Sporre, Dennis J., The Arts (Englewood Cliffs, NJ: Prentice-Hall, 1984).

10. Feldman, Edward Burke, Thinking About Art (Englewood Cliffs, NJ: Prentice-Hall, 1985).

11. Muller, Joseph-Emile, and Ramon Tio Bellido, A Century of Modern Painting (New York: Universe Books, 1985).

12. Arnason, H. H., History of Modern Art, Third edition (New York: Harry N. Abrams, 1986).

13. de la Croix, Horst; Richard G. Tansey, and Diane Kirkpatrick, Gardner's Art Through the Ages, Ninth edition (San Diego: Harcourt Brace Jovanovich, 1987).

14. Cole, Bruce, and Adelheid Gealt, Art of the Western World: From Ancient Greece to Post-Modernism (New York: Simon and Schuster, 1989).

15. Hartt, Frederick, A History of Painting, Sculpture, Architecture, Third edition (New York: Harry N. Abrams, 1989).

16. Tamplin, Ronald, editor, The Arts: A History of Expression in the $20^{\text {th }}$ Century (Oxford: Oxford University Press, 1991). 
17. Yenawine, Philip, How to Look at Modern Art (New York: Harry N. Abrams, 1991).

18. Hunter, Sam, and John Jacobus, Modern Art, Third edition (New York: Harry N. Abrams, 1992).

19. Sprocatti, Sandro, editor, A Guide to Art (New York: Harry N. Abrams, 1992).

20. Strickland, Carol, The Annotated Mona Lisa: A Crash Course in Art History from Prehistoric to Post-Modern (Kansas City: Andrews and McMeel, 1992).

21. Wheeler, Daniel, Art Since Mid-Century: 1945 to the Present (Englewood Cliffs, NJ: Prentice-Hall, 1992).

22. Silver, Larry, Art in History (Englewood Cliffs, NJ: Prentice-Hall, 1993).

23. *Wood, Paul; Francis Frascina; Jonathan Harris, and Charles Harrison, Modernism in Dispute: Art since the Forties (New Haven: Yale University Press, 1993).

24. *Adams, Laurie Schneider, A History of Western Art (New York: Harry N. Abrams, 1994).

25. Stangos, Nikos, editor, Concepts of Modern Art: From Fauvism to Postmodernism, Third edition (London: Thames and Hudson, 1994).

26. Fleming, William, Arts and Ideas, Ninth edition (Fort Worth: Harcourt Brace, 1995).

27. Janson, H. W., and Anthony F. Janson, History of Art, Fifth edition (New York: Harry N. Abrams, 1995).

28. Lucie-Smith, Edward, Movements in Art Since 1945: Issues and Concepts, Third edition (New York: Thames and Hudson, 1995).

29. *Stokstad, Marilyn, and Marion Spears Grayson, Art History (New York: Harry N. Abrams, 1995).

30. Baigell, Matthew, A Concise History of American Painting and Sculpture, Revised edition (New York: Harper and Row, 1996).

31. *Dawtrey, Liz; Toby Jackson; Mary Masterton; Pam Meecham, and Paul Wood, editors, Investigating Modern Art (New Haven: Yale University Press, 1996).

32. Kissick, John, Art: Context and Criticism, Second edition (Boston: McGraw-Hill, 1996). 
33. Gallup, Alison; Gerhard Gruitrooy, and Elizabeth M. Weisberg, Great Paintings of the Western World (New York: Hugh Lauter Levin Associates, 1997).

34. *Hughes, Robert, American Vision: The Epic History of Art in America (New York: Alfred A. Knopf, 1997).

35. Lucie-Smith, Edward, Visual Arts in the Twentieth Century (New York: Harry N. Abrams, 1997).

36. Tesch, Jurgen, and Eckhard Hollmann, editors, Icons of Art: The 20 ${ }^{\text {th }}$ Century (Munich: Prestel, 1997).

37. *Wilkins, David G.; Bernard Schultz, and Katheryn M. Linduff, Art Past, Art Present, Third edition (New York: Harry N. Abrams, 1997).

38. Freeman, Julian, Art: A Crash Course (New York: Watson-Guptill, 1998).

39. Gebhardt, Volker, The History of Art (New York: Barron's, 1998).

40. Walther, Ingo F., editor, Art of the $20^{\text {th }}$ Century, 2 volumes (Koln: Taschen, 1998).

41. Tobler, Jay, editor, The American Art Book (London: Phaidon, 1999).

42. Bocola, Sandro, The Art of Modernism: Art, Culture, and Society from Goya to the Present Day (Munich: Prestel Verlag, 1999).

43. Britt, David, editor, Modern Art: Impressionism to Post Modernism (New York: Thames and Hudson, 1999).

44. *Honour, Hugh, and John Fleming, The Visual Arts: A History, Fifth edition (New York: Harry N. Abrams, 1999).

45. Lucie-Smith, Edward, Lives of the Great 20 $0^{\text {th }}$-Century Artists (London: Thames and Hudson, 1999).

46. Preble, Duane; Sarah Preble, and Patrick Frank, Artforms: An Introduction to the Visual Arts, Sixth edition (New York: Longman, 1999).

47. Vaizey, Marina, editor, Art: The Critics' Choice (New York: Watson-Guptill, 1999).

48. Collings, Matthew, This Is Modern Art (New York: Watson-Guptill, 2000).

49. Fineberg, Jonathan, Art Since 1940: Strategies of Being, Second edition (New York: 
Harry N. Abrams, 2000).

50. *Hopkins, David, After Modern Art 1945-2000 (Oxford: Oxford University Press, 2000).

51. *Kemp, Martin, editor, The Oxford History of Western Art (Oxford University Press, 2000).

52. Parmesani, Loredana, Art of the Twentieth Century (Milan: Skira, 2000).

53. Bell, Cory, Modern Art: A Crash Course (New York: Watson-Guptill, 2001).

54. *Bjelajac, David, American Art: A Cultural History (New York: Harry N. Abrams, 2001).

55. Hodge, Nicola, and Libby Anson, The A-Z of Art: The World's Greatest Artists and Their Works (London: Carlton Books, 2001).

56. Richter, Klaus, Art: From Impressionism to the Internet (Munich: Prestel, 2001). 